\author{
St ud i a P ilosophic a \\ Wrat i s l a vi e n s i a \\ vol. XV, fasc. $2(2020)$ \\ https://doi.org/10.19195/1895-8001.15.2.13
}

MAREK MAGDZIAK

ORCID: 0000-0002-5465-4451

Uniwersytet Wrocławski

\title{
Uwagi o abstrakcji, ufundowaniu i hipostazie
}

\author{
Remarks on Abstraction, Foundation, and Hypostasis
}

\begin{abstract}
The article deals with philosophical issues concerning abstraction and concreteness, focusing on selected ontological and logical-ontological threads of this difficult and intricate problem. Thus, it will concern first of all abstract and concrete objects, and only then abstract representations and judgments and concrete representations and judgments. The subject of interest will also be the process of abstraction and the relations that take place between abstract objects such as features or relations, pure qualities, and ideal objects.
\end{abstract}

Keywords: abstraction, abstract object, hypostasis, pure quality, ideal object

\section{Wprowadzenie}

Filozoficzna problematyka dotycząca abstrakcji, a co za tym idzie także konkretu, jest bardzo złożona i wielowątkowa. Dlatego skupię się tu jedynie na wybranych wątkach ontologicznych i logiczno-ontologicznych tej trudnej i zawiłej problematyki.

Poniższe uwagi dotyczyć więc będą tego, co abstrakcyjne, i tego, co konkretne, a zatem przede wszystkim przedmiotów abstrakcyjnych oraz przedmiotów konkretnych, a dopiero potem przedstawień i sądów abstrakcyjnych oraz przedstawień i sądów konkretnych. Przyjmuję tu bowiem założenie, że przedstawienia abstrakcyjne to takie przedstawienia, które za swe przedmioty maja przedmioty abstrakcyjne, przedstawienia zaś konkretne to takie przedstawienia, które za swe przedmioty maja przedmioty konkretne. Analogicznie jest w wypadku sądów abstrakcyjnych i sądów konkretnych. Abstrakcyjny lub konkretny charakter przedstawień lub sądów zależy zatem od tego, jaki charakter (abstrakcyjny czy konkretny) mają ich 
przedmioty. Termin „abstrakcja” pełni także jeszcze inną ważną funkcję. Przez abstrakcję można bowiem rozumieć proces przechodzenia od przedstawień czy sądów konkretnych do przedstawień czy sądów abstrakcyjnych. Proces taki nazywany jest także „procesem abstrahowania”.

Punktem wyjścia, a zarazem tłem poniższych rozważań niech będą obszerne i systematyczne analizy Husserla zawarte w drugim tomie Badań logicznych ${ }^{1}$. Celem moim nie jest tu jednak ani historia problematyki abstrakcji i konkretu, ani rekonstrukcja stanowiska Husserla.

\section{Przedmioty abstrakcyjne i konkretne}

Przedmiot a b st r a k c y j ny to taki, którego forma sprawia, że aby istnieć, musi on współistnieć z pewnym innym przedmiotem (lub z pewnymi innymi) w obrębie pewnej większej całości. Przykładem przedmiotu abstrakcyjnego jest choćby cecha pewnej rzeczy, na przykład zabarwienie (pewnego określonego) jabłka. Cecha pewnej rzeczy może bowiem istnieć tylko wraz z tą rzeczą — jest atrybut em tejże rzeczy, a rzecz ta stanowi dla niej s ubst an c ję, czyli konieczne podłoże. Można także powiedzieć, że cecha taka jest ufundowan a w rzeczy, której przysługuje. Husserl łączy częstokroć pojęcie przedmiotu abstrakcyjnego z pojęciem części abstrakcyjnej pewnego przedmiotu. Chodzi tu o to, że wyróżniając w pewnym przedmiocie jego części, można wyróżnić części samodzielne tego przedmiotu (inaczej kawałki), które mogą istnieć samodzielnie po oddzieleniu ich od tego przedmiotu, oraz części niesamodzielne tego przedmiotu (inaczej momenty), które nie mogą istnieć w oddzieleniu od tego przedmiotu. Na przykład za część (pewnego określonego) jabłka można uznać zarówno zabarwienie tego jabłka, jak i jego ogonek lub każdą jego pestkę. Oczywiście ogonek lub pestka tego jabłka to przedmioty konkretne, mogą one bowiem istnieć niezależnie od tego, czy jabłko to istnieje, czy téz nie. Nie są więc one ufundowane w tym jabłku, są jego częściami, lecz nie są jego atrybutami. Nie każdy przedmiot abstrakcyjny jest jednak częścią przedmiotu, w którym jest ufundowany. Załóżmy, że na stole, przy którym właśnie siedzę, leży (pewne określone) jabłko i (pewna określona) gruszka. Weźmy teraz pod uwagę odległość, jaka dzieli to jabłko od tej gruszki. Oczywiście odległość ta może istnieć, jedynie współistniejąc z tym jabłkiem i z tą gruszką w obrębie pewnej większej całości. Jest ona zatem ufundowana zarówno w tym jabłku, jak i w tej gruszce. Jest więc czymś abstrakcyjnym. Nie jest ona jednak ani częścią tego jabłka, ani częścią tej gruszki. Tą większą całością, w obrębie której odległość ta, aby istnieć, musi współistnieć z tym jabłkiem i z tą gruszką, nie jest bowiem ani to jabłko, ani ta gruszka, lecz stan rzeczy polegający na tym, że to jabłko leży w pewnej odległości od tej gruszki². Przedmiot konkretny to natomiast taki przedmiot, który aby

${ }^{1}$ Badanie II: Idealna jedność species a nowożytne teorie abstrakcji oraz badanie III: Z nauki o całościach $i$ częściach; zob. E. Husserl, Badania logiczne, t. 2. Badania dotyczace fenomenologii i teorii poznania, cz. 1, tłum. J. Sidorek, Warszawa 2000, s. 131-366.

2 Oczywiście jest tak pod warunkiem, że odrzuca się tak zwaną teorię relacji wewnętrznych. Teoria ta była rozwijana na przykład w neoidealizmie brytyjskim. Zdaniem piszaccego te słowa do teorii relacji 
istnieć, nie musi wcale współistnieć z pewnym innym przedmiotem (lub z pewnymi innymi przedmiotami) w obrębie pewnej większej całości. Przykładem przedmiotu konkretnego będzie więc zarówno pewne jabłko, pewna gruszka, jak i ogonek czy pestka tego jabłka lub tej gruszki.

\section{Przedstawienia i sądy}

Do tej pory była mowa o przedmiotach abstrakcyjnych i o przedmiotach konkretnych. Jak już wcześniej powiedziałem, przedmioty abstrakcyjne to przedmioty ufundowane w pewnych innych przedmiotach, czyli takie, które aby istnieć, muszą współistnieć z pewnymi innymi przedmiotami w obrębie pewnych większych całości. Można teraz zadać pytanie, czy pomiędzy przedstawieniami abstrakcyjnymi i przedstawieniami konkretnymi oraz pomiędzy sądami abstrakcyjnymi oraz sądami konkretnymi nie zachodzi pewnego rodzaju stosunek analogiczny do stosunku ufundowania. Można bowiem zapytać, czy każde przedstawienie abstrakcyjne jest ufundowane w pewnym przedstawieniu konkretnym i czy każdy sąd abstrakcyjny jest ufundowany w pewnym sądzie konkretnym. Ale co to pytanie dokładnie znaczy? To, że każde przedstawienie abstrakcyjne jest ufundowane w pewnych przedstawieniach konkretnych, można rozumieć tak, że każde przedstawienie, którego przedmiotem jest pewien przedmiot abstrakcyjny, może istnieć, jedynie współistniejąc w obrębie pewnej większej całości z przedstawieniem (lub przedstawieniami), którego przedmiotem jest (lub których przedmiotami są) przedmiot (lub przedmioty), w którym (lub w których) ufundowany jest ów przedmiot abstrakcyjny. To znaczy, że jeśli przedstawiamy sobie pewną cechę, to tym samym przedstawić sobie musimy pewną substancję, która tę cechę ma, podobnie jeśli przedstawiamy sobie pewną relację, to przedstawić musimy sobie także pewne substancje, które pozostaja do siebie w tej relacji. Podobnie jest w przypadku sądów. Można tutaj zapytać, czy każdy sąd abstrakcyjny jest ufundowany w pewnych sądach konkretnych. To znaczy, czy każdy sąd, którego przedmiotem jest przedmiot abstrakcyjny, może istnieć, jedynie współistniejąc w obrębie większej całości z sądem (lub sądami), którego przedmiotem jest (lub których przedmiotami są) przedmiot (lub przedmioty), w którym ufundowany jest ów przedmiot abstrakcyjny. W wypadku sądów owymi całościami są pewne (niesprzeczne) teorie. Dlatego pytanie, czy każdy sąd abstrakcyjny jest ufundowany w pewnych sądach konkretnych, sprowadza się do pytania, czy każda teoria, która zawiera pewne sądy abstrakcyjne, musi także zawierać pewne sądy konkretne, których przedmiotami są przedmioty, w których ufundowane są przedmioty tychże abstrakcyjnych sądów. Z czysto logicznego punktu widzenia możliwe są (niesprzeczne) teorie, które jako swe tezy zawierają pewne sądy abstrakcyjne, natomiast nie zawierają żadnych sądów konkretnych, których przedmiotami byłyby przedmioty, w których ufundowane są przedmioty tych abstrakcyjnych sądów. Możliwe są na przykład takie teorie, które zawierają tezę stwierdzającą, że są przedmioty mające pewną okre-

wewnętrznych doskonale stosują się uwagi J. Swifta; zob. idem, Podróże Gullivera, tłum. M. Słomczyński, Wrocław 1988 , s. $187^{14-16}$. 
śloną cechę, lecz niezawierające żadnej tezy stwierdzającej, że pewien przedmiot konkretny ową cechę ma. Za przykład mogą tu posłużyć $\omega$-sprzeczne teorie pierwszego rzędu. W przypadku przedstawień sprawa nie jednak tak prosta. Nie bardzo bowiem wiadomo, czym miałyby być owe większe całości złożone z przedstawień. Całości takie, czyli pewne spójne kompleksy przedstawień (analogiczne do teorii jako pewnych spójnych kompleksów sądów), nazwiemy tu ogląda mi. Dlatego pytanie, czy każde przedstawienie abstrakcyjne jest ufundowane w pewnych przedstawieniach konkretnych, sprowadza się do pytania, czy każdy ogląd, który zawiera pewne przedstawienia abstrakcyjne, musi także zawierać pewne przedstawienia konkretne, których przedmiotami są przedmioty, w których ufundowane są przedmioty tychże abstrakcyjnych przedstawień. Oczywiście na to pytanie nie sposób odpowiedzieć. Trzeba by najpierw zbudować jakąś logikę oglądów albo sięgnąć do wyników badań z zakresu psychologii deskryptywnej³ ${ }^{3}$

\section{Ufundowanie}

Jak wcześniej powiedziano, każdy przedmiot abstrakcyjny jest ufundowany w pewnym innym przedmiocie, który stanowi jego substancję lub, inaczej mówiąc, jest jego podłożem ${ }^{4}$. Ten ostatni przedmiot może z kolei być zarówno przedmiotem konkretnym, jak i przedmiotem abstrakcyjnym. W tym ostatnim wypadku wymaga on znowu kolejnego przedmiotu, w którym jest ufundowany. Jeśli teraz spojrzy się na uniwersum ontologiczne (czyli na klasę wszystkich możliwych przedmiotów) pod kątem porządkującego to uniwersum stosunku ufundowania, to możemy zapytać, czy możliwe są nieskończone zstępujące łańcuchy przedmiotów uporządkowanych przez tenże stosunek. Jeśli nie, to każdy przedmiot jest ostatecznie ufundowany w przedmiocie lub w przedmiotach, które same nie wymagają już ufundowania, czyli są konkretne. Przedmioty takie to substancje pierwsze ${ }^{5}$. Pogląd, że każdy przedmiot jest ostatecznie ufundowany w substancjach pierwszych, ma długą historię. Teorie ontologiczne, które przyjmują tenże pogląd, nazywać będę ontologiami ufundowanymi. Przykładem takiej ufundowanej ontologii jest pewien intuicyjny model teorii mnogości, mianowicie hierarchia Zermela (nazywana także hierarchią kumulatywną). Zasadniczym pytaniem związanym z każdym intuicyjnym modelem teorii mnogości jest pytanie o to, czym są przedmioty tejże teorii, czyli zbiory. W przypadku hierarchii Zermela odpowiedź jest następująca: istnieją pewne przedmioty, które nie są zbiorami. Przedmioty te nazywamy praelementami. Są one odpowiednikami substancji pierwszych. Z praelementów tworzą się klasy, a następnie klasy złożone z praelementów i utworzonych wcześniej klas

\footnotetext{
${ }^{3}$ Piszący te słowa ma pewne wątpliwości, czy istnieją takie ustalenia z zakresu psychologii deskryptywnej, które stanowiłyby jakąkolwiek podstawę definitywnego rozwiązania tego problemu.

${ }^{4}$ Oczywiście przedmiot abstrakcyjny może być także ufundowany w wielu różnych przedmiotach, które stanowią dla niego podłoże. Ze względu na większość jasność wywodów aspekt ten, jako oczywisty, będę tu pomijać.

${ }^{5}$ Używam tu terminu, i jedynie terminu, wprowadzonego przez Arystotelesa; zob. idem, Kategorie, 2a w: idem, Kategorie $i$ hermeneutyka z dodaniem Isagogi Porfiriusza, tłum. K. Leśniak, Warszawa 1975 , s. $6-7$.
} 
i tak dalej. Inaczej mówiąc, w punkcie wyjścia mamy praelementy. Pierwszy etap to łączenie się praelementów w klasy. Drugi etap to łączenie się w klasy przedmiotów, które są albo praelementami, albo klasami utworzonymi w pierwszym etapie. Ogólnie rzecz biorąc, w każdym kolejnym etapie mogą tworzyć się klasy przedmiotów, które są albo praelementami, albo klasami utworzonymi w poprzednich etapach. Zbiorem jest każdy i tylko taki przedmiot, który powstał w jakimś z kolejnych etapów. Dlatego każdy zbiór jest ostatecznie zbudowany z praelementów, a zatem każdy przedmiot teorii mnogości jest ostatecznie ufundowany w substancjach pierwszych. Oczywiście to jedynie przykład. Ogólnie można jednak zapytać, czy ontologie ufundowane są tak oczywiste, że nie powinny być nigdy podważane. Zobaczmy zatem, jakie konsekwencje może przynieść odrzucenie założenia o ufundowaniu.

Po pierwsze, może to prowadzić do poglądu, że możliwe są nieskończone zstępujące łańcuchy przedmiotów uporządkowanych przez stosunek ufundowania. W tym przypadku mamy do czynienia z pewną postacią regresu ad infinitum. Sytuacja taka nie jest oczywiście logicznie niemożliwa, lecz na pewno w tradycji filozoficznej nie była nigdy mile widziana. Po drugie, może to prowadzić do poglądu, że możliwe są pary, trójki czy ogólniej entki przedmiotów, które wzajemnie się fundują, czyli tak zwane pętle. Po trzecie, możliwa jest także sytuacja, w której co prawda każdy przedmiot jest ostatecznie ufundowany w pewnych przedmiotach podstawowych (nazwijmy je przedmiotami pierwszego rzędu), ale przedmioty te nie są substancjami pierwszymi, lecz pewnymi kompleksami wzajemnie się fundujących przedmiotów. Obiekt pierwszego rzędu może więc tu być całością zbudowaną z części, które są względem siebie wzajemnie niesamodzielne, lecz razem tworzą pewną samodzielną całość.

\section{Hipostaza, przedmioty abstrakcyjne i przedmioty idealne}

Jeszcze innym ważnym aspektem problematyki tego, co abstrakcyjne, i tego, co konkretne, jest hi p ost a za. Przez hipostazę rozumiem tu przeistoczenie tego, co abstrakcyjne, w to, co konkretne, czyli na przykład przejście od cechy (pewnej rzeczy) do czystej jakości, która ową rzecz determinuje, lecz która nie jest już w niej ufundowana. Odpowiednio przez hipostazowanie rozumieć będę przechodzenie od ujmowania pewnego przedmiotu abstrakcyjnego, takiego jak cecha pewnej rzeczy (na przykład bycie przez tę rzecz czerwoną), do ujmowania pewnego przedmiotu konkretnego, takiego jak jakość idealna determinująca rzecz mającą tęże cechę (na przykład czerwień). Dla większej jasności wprowadzę tu pewną nieformalną notację. Przedmioty konkretne oznaczane będą małymi literami a, b, c..., przedmioty zaś abstrakcyjne, takie jak cechy czy relacje, dużymi literami A, B, C... Dlatego napis A(b) oznaczać będzie przedmiot b mający cechę A, na przykład czerwone jabłko (dokładniej, to oto czerwone jabłko). Natomiast napis B(c, d) oznaczać będzie przedmiot c pozostający w relacji A do przedmiotu d, na przykład gruszkę leżącą tuż obok banana albo stykającą się z bananem (dokładniej, tę oto gruszkę stykającą się z tym oto bananem). Można także uwzględnić relacje trój- i więcej 
-argumentowe, ale nie będziemy tego tutaj robić. Symbole takie jak A(b) i B(c, d) oznaczaja przedmioty konkretne, takie jak czerwone jabłko czy gruszka leżąca tuż obok banana.

Przedmioty abstrakcyjne, takie jak bycie czerwonym czy ogólniej cecha lub leżenie tuż obok czy ogólniej — relacja dwuargumentowa, oznaczane będą przy pomocy wyrażeń zawierających zmienne, takich jak A(x) czy B(x, y). Symbol A(x) oznacza zatem cechę posiadaną przez jakiś (nieokreślony) przedmiot, na przykład bycie przez coś (nieokreślonego) czerwonym. Symbol B(x, y) oznacza zaś relację, w której coś (nieokreślonego) pozostaje do czegoś innego (równie nieokreślonego), na przykład leżenie czegoś tuż obok czegoś innego. Oczywiście przedmioty abstrakcyjne, takie jak cechy czy relacje, to przedmioty niepełne lub, używając terminologii Fregego, niekompletne, czyli takie, które domagają się dopełnienia przez coś innego. Owa niekompletność zaznaczona jest w przyjętej tu symbolice właśnie poprzez użycie zmiennych. Przejście od ujmowania przedmiotów takich jak czerwone jabłko i oznaczających te przedmioty wyrażeń o postaci A(b) czy od ujmowania przedmiotów takich jak gruszka stykająca się z bananem i oznaczających je wyrażeń o postaci $\mathrm{B}(\mathrm{c}, \mathrm{d})$ do przedmiotów takich jak bycie przez coś (nieokreślonego) czerwonym i oznaczających je wyrażeń o postaci $\mathrm{A}(\mathrm{x})$ i odpowiednio do przedmiotów takich jak leżenie czegoś tuż obok czegoś innego i oznaczających je wyrażeń o postaci $\mathrm{B}(\mathrm{x}, \mathrm{y})$ to abstrahowanie, czyli przejście od ujmowania tego, co konkretne, do ujmowania tego, co abstrakcyjne.

Przyjęta tu symbolika może wydać się identyczna z tą, która jest powszechnie stosowana w logice pierwszego rzędu. Jest jednak inaczej. Wyrażenia takie jak A(b) czy B (c, d) reprezentują tu przedstawienia, czyli akty ujmowania pewnych przedmiotów (na przykład jako mających pewne cechy lub pozostających do pewnych innych przedmiotów w określonych relacjach). Natomiast w logice pierwszego rzędu wyrażenia takie jak A(b) czy B(c, d) reprezentują sądy, czyli akty, w których sądzi się (lub stwierdza się), że pewne przedmioty mają pewne cechy lub że pewne przedmioty pozostają do pewnych innych przedmiotów w określonych relacjach.

Kolejnym krokiem jest przejście od przedmiotów abstrakcyjnych do odpowiadających im czystych jakości (lub jakości idealnych), które na powrót stają się przedmiotami konkretnymi. Proces ten to hipostaza. Prowadzi ona od cech takich jak bycie przez coś czerwonym lub relacji takich jak leżenie czegoś tuż obok czegoś do czystych (lub idealnych) jakości, takich jak czerwień, lub czystych stosunków, takich jak stykanie się. Przez x/A(x) oznaczać więc będę czystą jakość odpowiadającą cesze $\mathrm{A}(\mathrm{x})$. Symbol / jest więc operatorem wiążącym zmienne, dlatego poprzedzenie wyrażenia $\mathrm{A}(\mathrm{x})$ wyrażeniem x/ prowadzi do związania występującej w wyrażeniu $\mathrm{A}(\mathrm{x})$ zmiennej $\mathrm{x}$, i przekształcenia wyrażenia $\mathrm{A}(\mathrm{x})$ oznaczającego przedmiot niekompletny, czyli abstrakcyjny, w wyrażenie x/A(x) oznaczające przedmiot kompletny, czyli konkretny, mianowicie w pewną jakość idealną. Podobnie przez $\mathrm{x} /(\mathrm{y} / \mathrm{B}(\mathrm{x}, \mathrm{y}))$ oznaczać będziemy czysty stosunek odpowiadający relacji $\mathrm{B}(\mathrm{x}, \mathrm{y})$. W tym przypadku operator / wiąże (kolejno) obie zmienne występujące w wyrażeniu B(x, y), przekształcając je z wyrażenia oznaczającego przedmiot niekompletny, czyli relację, w przedmiot kompletny, czyli czysty stosunek. 
Przedmioty konkretne (czyli kompletne) można z sobą łączyć, tworząc przedmioty złożone. Przez a * b oznaczać będę przedmiot złożony, którego bezpośrednimi składnikami (lub częściami) są przedmioty a i b, czyli przedmiot powstały poprzez dodanie przedmiotu a do przedmiotu b. Symbol * oznaczać więc będzie operację złożenia lub fuzji — operację, która od konkretnych przedmiotów a i b prowadzi do konkretnego przedmiotu a * b, stanowiącego złożenie lub fuzję przedmiotów a oraz b. Naturalne wydaje się zatem przypuszczenie, że jeśli pewną jakość idealną dodamy do pewnego przedmiotu, to w wyniku tego otrzymamy tenże przedmiot mający cechę odpowiadającą tejże jakości. Dla dowolnej cechy A(x) i dowolnego przedmiotu a możemy zatem przyjąć, że

(1) $\mathrm{x} / \mathrm{A}(\mathrm{x}) * \mathrm{~b}=\mathrm{A}(\mathrm{b})$.

Istotnie, jeśli jakość idealną $\mathrm{x} / \mathrm{A}(\mathrm{x})$ doda się do przedmiotu b, to otrzyma się przedmiot b mający cechę $\mathrm{A}(\mathrm{x})$, czyli przedmiot $\mathrm{A}(\mathrm{b})$.

Podobnie jest w przypadku relacji i odpowiadających im czystych stosunków. Dla dowolnej relacji $\mathrm{A}(\mathrm{x}, \mathrm{y})$ i dla dowolnych przedmiotów b i c, mamy:

(2) $\mathrm{x} /(\mathrm{y} / \mathrm{A}(\mathrm{x}, \mathrm{y})) * \mathrm{~b}=\mathrm{y} / \mathrm{A}(\mathrm{b}, \mathrm{y})$

oraz

(3) $\mathrm{y} /(\mathrm{x} / \mathrm{A}(\mathrm{x}, \mathrm{y})) * \mathrm{c}=\mathrm{x} / \mathrm{A}(\mathrm{x}, \mathrm{c})$,

a także

(4) $(\mathrm{x} /(\mathrm{y} / \mathrm{A}(\mathrm{x}, \mathrm{y})) * \mathrm{~b}) * \mathrm{c}=\mathrm{y} / \mathrm{A}(\mathrm{b}, \mathrm{y}) * \mathrm{c}=\mathrm{A}(\mathrm{b}, \mathrm{c})$.

Istotnie, jeśli czysty stosunek $\mathrm{x} /(\mathrm{y} / \mathrm{A}(\mathrm{x}, \mathrm{y}))$ doda się do przedmiotu b, a następnie to, co otrzymano, doda się do przedmiotu c, to otrzyma się przedmiot b pozostający do przedmiotu c w relacji $\mathrm{A}(\mathrm{x}, \mathrm{y})$, czyli przedmiot $\mathrm{A}(\mathrm{b}, \mathrm{c})$.

Tak samo dzieje się w przypadku relacji trójargumentowych i odpowiadajacych im czystych konfiguracji. Dla dowolnej relacji trójargumentowej $\mathrm{A}(\mathrm{x}, \mathrm{y}, \mathrm{z})$ i dla dowolnych przedmiotów b, c i d, mamy:

(5) $(\mathrm{x} /(\mathrm{y} /(\mathrm{z} / \mathrm{A}(\mathrm{x}, \mathrm{y}, \mathrm{z})) * \mathrm{~b}) * \mathrm{c}) * \mathrm{~d}=(\mathrm{y} /(\mathrm{z} / \mathrm{A}(\mathrm{b}, \mathrm{y}, \mathrm{z})) * \mathrm{c}) * \mathrm{~d}=\mathrm{z} / \mathrm{A}(\mathrm{b}, \mathrm{c}, \mathrm{z})$ $* \mathrm{~d}=\mathrm{A}(\mathrm{b}, \mathrm{c}, \mathrm{d})$.

Istotnie, jeśli czystą konfigurację $\mathrm{x} /(\mathrm{y} /(\mathrm{z} / \mathrm{A}(\mathrm{x}, \mathrm{y}, \mathrm{z})))$ doda się kolejno do przedmiotów b, c i d, to otrzyma się przedmiot b pozostający do przedmiotów c i d w relacji trójargumentowej A(x, y, z), czyli przedmiot A(b, c, d).

Powyższe uwagi opierały się na trzech istotnych założeniach.

Po pierwsze, od dowolnego przedmiotu konkretnego, takiego jak to oto czerwone jabłko, można zawsze przejść do przedmiotu abstrakcyjnego, takiego jak bycie 
czerwonym. Przejście to może być zawsze dokonane za pośrednictwem procesu abstrakcji.

Po drugie, od dowolnego przedmiotu abstrakcyjnego, takiego jak bycie czerwonym, można zawsze przejść do czystej jakości, takiej jak czerwień. Przejście to może być zawsze dokonane za pośrednictwem procesu hipostazy.

Po trzecie wreszcie, dwa dowolne przedmioty konkretne można zawsze z sobą połączyć, otrzymując w wyniku tego także pewien przedmiot konkretny, a co więcej - dodanie pewnej jakości idealnej do dowolnie ustalonego przedmiotu daje w wyniku tenże przedmiot mający cechę odpowiadającą tejże jakości.

\section{Podsumowanie}

Przedstawię teraz trzy wybrane wnioski, które wynikają z tych założeń.

Wniosek 1. Dla dowolnej cechy $\mathrm{A}(\mathrm{x})$ jest taki przedmiot $\mathrm{b}$, że $\mathrm{b}=\mathrm{A}(\mathrm{b})$.

Przedmiot $b$ jest więc identyczny z przedmiotem $b$ majacym cechę $A(x)$. Przedmiot taki można więc nazwać przedmiotem idealnym ze względu na cechę $\mathrm{A}(\mathrm{x})$. Dlatego dla dowolnie ustalonej cechy $\mathrm{A}(\mathrm{x})$ jest taki przedmiot konkretny, który jest przedmiotem idealnym ze względu na cechę $\mathrm{A}(\mathrm{x})$. Inaczej mówiąc, przedmiot $\mathrm{b}$ to taki przedmiot, który z konieczności ma cechę $\mathrm{A}(\mathrm{x})$. Zatem, mówiąc jeszcze inaczej, dla dowolnie ustalonej cechy $\mathrm{A}(\mathrm{x})$ jest taki przedmiot, który z konieczności tę że cechę ma.

Dowód: Niech A(x) będzie dowolnie ustaloną cechą. Weźmy teraz pod uwagę dowolnie ustalony przedmiot c, a następnie złożenie, czy fuzję c ${ }^{*}$ c. Rozważmy dalej przedmiot konkretny $\mathrm{A}(\mathrm{c} * \mathrm{c})$, a następnie cechę $\mathrm{A}(\mathrm{x} * \mathrm{x})$ i ostatecznie czystą jakość $\mathrm{x} / \mathrm{A}\left(\mathrm{x}^{*} \mathrm{x}\right)$. Spójrzmy teraz na fuzję $\mathrm{x} / \mathrm{A}(\mathrm{x} * \mathrm{x}) * \mathrm{x} / \mathrm{A}(\mathrm{x} * \mathrm{x})$. Otóż na mocy (1) mamy:

$\mathrm{x} / \mathrm{A}(\mathrm{x} * \mathrm{x}) * \mathrm{x} / \mathrm{A}(\mathrm{x} * \mathrm{x})=\mathrm{A}(\mathrm{x} / \mathrm{A}(\mathrm{x} * \mathrm{x}) * \mathrm{x} / \mathrm{A}(\mathrm{x} * \mathrm{x}))=\mathrm{A}(\mathrm{A}(\mathrm{x} / \mathrm{A}(\mathrm{x} * \mathrm{x}) *$
$\mathrm{x} / \mathrm{A}(\mathrm{x} * \mathrm{x})))=\ldots$

Dla dowolnego $\mathrm{A}(\mathrm{x})$, jest więc takie $\mathrm{b}$, że $\mathrm{b}=\mathrm{A}(\mathrm{b})=\mathrm{A}(\mathrm{A}(\mathrm{b}))=\ldots$

Istotnie, $\mathrm{b}=\mathrm{x} / \mathrm{A}(\mathrm{x} * \mathrm{x}) * \mathrm{x} / \mathrm{A}(\mathrm{x} * \mathrm{x})$.

Wniosek pierwszy jest $\mathrm{w}$ pewnym sensie uogólnieniem rozumowania Kartezjusza nawiązującego w pewnym sensie do ratio Anselmi. Otóż zdaniem Kartezjusza, jeśli posiadamy ideę doskonałości, to jest taki przedmiot, który jest z konieczności przedmiotem doskonałym. Można tu oczywiście zapytać: co to znaczy, że posiadamy ideę doskonałości lub jakąkolwiek inną ideę? Otóż, jak sądzę, posiadamy ideę pewnej cechy wtedy, gdy ujmujemy pewien przedmiot jako przedmiot mający tę cechę bądź jako przedmiot, który tej cechy nie ma. W szczególności posiadamy ideę doskonałości, o ile pewne przedmioty ujmujemy jako przedmioty doskonałe lub pewne przedmioty ujmujemy jako przedmioty niedoskonałe. Zgodnie z pierwszym wnioskiem, jeśli pewien przedmiot ujmujemy jako przedmiot mający pewną cechę $\mathrm{A}(\mathrm{x})$ lub jako przedmiot, które cechy tej nie ma, to jest taki przedmiot, który z konieczności ma cechę $\mathrm{A}(\mathrm{x})$. W szczególności, jeśli jest taki przedmiot, 
który ujmujemy jako przedmiot doskonały, to jest też taki przedmiot, który jest z konieczności przedmiotem doskonałym. Podobnie, jeśli jest taki przedmiot, który ujmujemy jako przedmiot niedoskonały, to jest też taki przedmiot, który jest z konieczności przedmiotem doskonałym. Ta ostatnia wersja jest zresztą bliższa oryginalnej argumentacji Kartezjusza ${ }^{6}$.

Wniosek 2. Dla dowolnej dwuargumentowej relacji A(x, y) jest taki przedmiot $\mathrm{b}, \dot{\mathrm{z} e} \mathrm{~b}=\mathrm{A}(\mathrm{b}, \mathrm{b})$.

Przedmiot b jest więc identyczny z przedmiotem b pozostającym do samego siebie $\mathrm{w}$ relacji $\mathrm{A}(\mathrm{x}, \mathrm{y})$. Przedmiot taki możemy więc nazwać przedmiotem idealnym ze względu na relację $\mathrm{A}(\mathrm{x}, \mathrm{y})$. Dlatego dla dowolnie ustalonej dwuargumentowej relacji $\mathrm{A}(\mathrm{x}, \mathrm{y})$ jest taki przedmiot konkretny, który jest przedmiotem idealnym ze względu na relację $\mathrm{A}(\mathrm{x}, \mathrm{y})$. Inaczej mówiąc, przedmiot b to taki przedmiot, który z konieczności pozostaje do samego siebie w relacji A(x, y). Zatem, mówiąc jeszcze inaczej, dla dowolnie ustalonej dwuargumentowej relacji $\mathrm{A}(\mathrm{x}, \mathrm{y})$ jest taki przedmiot, który z konieczności pozostaje w tejże relacji do samego siebie.

Dowód: N iech A(x, y) będzie dowolnie ustaloną relacją dwuargumentową. Weźmy teraz pod uwagę dwa dowolnie ustalone przedmioty c oraz d, a następnie złożenia, czy fuzje $(\mathrm{c} * \mathrm{c}) * \mathrm{c}$ i $(\mathrm{d} * \mathrm{~d}) * \mathrm{~d}$. Rozważmy dalej przedmiot konkretny $\mathrm{A}((\mathrm{c} * \mathrm{c}) * \mathrm{c},(\mathrm{d} * \mathrm{~d}) * \mathrm{~d})$, a następnie cechę $\mathrm{A}((\mathrm{x} * \mathrm{x}) * \mathrm{x},(\mathrm{y} * \mathrm{y}) * \mathrm{y})$ i ostatecznie czystą jakość $\mathrm{x} /(\mathrm{y} / \mathrm{A}((\mathrm{x} * \mathrm{x}) * \mathrm{x},(\mathrm{y} * \mathrm{y}) * \mathrm{y}))$. Jakość tę oznaczmy przez a. Spójrzmy teraz na fuzję (a * a) * a. Otóż na mocy (1) i (4) mamy:

$$
\begin{aligned}
& (\mathrm{a} * \mathrm{a}) * \mathrm{a}= \\
& (\mathrm{x} /(\mathrm{y} / \mathrm{A}((\mathrm{x} * \mathrm{x}) * \mathrm{x},(\mathrm{y} * \mathrm{y}) * \mathrm{y})) * \mathrm{a}) * \mathrm{a}= \\
& \mathrm{y} / \mathrm{A}((\mathrm{a} * \mathrm{a}) * \mathrm{a},(\mathrm{y} * \mathrm{y}) * \mathrm{y}) * \mathrm{a}= \\
& \mathrm{A}((\mathrm{a} * \mathrm{a}) * \mathrm{a},(\mathrm{a} * \mathrm{a}) * \mathrm{a})
\end{aligned}
$$

Dla dowolnego $\mathrm{A}(\mathrm{x}, \mathrm{y})$ jest więc takie $\mathrm{b}$, że $\mathrm{b}=\mathrm{A}(\mathrm{b}, \mathrm{b})$.

Istotnie $\mathrm{b}=(\mathrm{a} * \mathrm{a}) * \mathrm{a}$ lub, pomijając skrót definicyjny, $\mathrm{b}=(\mathrm{x} /(\mathrm{y} / \mathrm{A}((\mathrm{x} * \mathrm{x})$ $* \mathrm{x},(\mathrm{y} * \mathrm{y}) * \mathrm{y})) * \mathrm{x} /(\mathrm{y} / \mathrm{A}((\mathrm{x} * \mathrm{x}) * \mathrm{x},(\mathrm{y} * \mathrm{y}) * \mathrm{y}))) * \mathrm{x} /(\mathrm{y} / \mathrm{A}((\mathrm{x} * \mathrm{x}) * \mathrm{x},(\mathrm{y} *$ y) $*$ y)).

Wniosek drugi wiąże się z kolei z ideą causa sui wiązaną zwykle z postacią Benedykta de Spinozy. Otóż zdaniem Spinozy, jeśli posiadamy ideę przyczyny, to jest taki przedmiot, który jest z konieczności swoją własną przyczyną7. Podobnie jak wcześniej powiemy, że posiadamy ideę przyczyny, wtedy gdy ujmujemy pewien przedmiot jako przyczynę pewnego innego przedmiotu, lub ogólniej, że posiadamy ideę pewnej relacji, gdy ujmujemy pewien przedmiot jako pozostający w tej relacji do pewnego innego przedmiotu. Zgodnie z drugim wnioskiem, jeśli pewien przedmiot ujmujemy jako przedmiot pozostający do pewnego innego przedmiotu w relacji $\mathrm{A}(\mathrm{x}, \mathrm{y})$, to jest taki przedmiot, który z konieczności pozostaje sam z sobą w relacji $\mathrm{A}(\mathrm{x}, \mathrm{y})$. W szczególności, jeśli jest taki przedmiot, który ujmujemy jako

${ }^{6}$ Np. R. Descartes, Rozprawa o metodzie. Część czwarta w: idem, Rozprawa o metodzie, tłum. W. Wojciechowska, Warszawa 1981, s. 37-48.

${ }^{7}$ B. de Spinoza, Etyka, cz. 1. O bóstwie w: idem, Etyka, tłum. I. Myślicki, Warszawa 1991, s. 3-34. 
przedmiot będący przyczyną pewnego innego przedmiotu, to jest też taki przedmiot, który jest z konieczności swoją własną przyczyną.

Wniosek 3. Dla dowolnie ustalonych cech $\mathrm{A}(\mathrm{x})$ i $\mathrm{B}(\mathrm{x})$ są takie przedmioty c i d, że c $=\mathrm{A}(\mathrm{d})$ i d $=\mathrm{B}(\mathrm{c})$.

Przedmiot $c$ jest więc identyczny $z$ przedmiotem d mającym cechę $A(x)$, a przedmiot d jest identyczny z przedmiotem c posiadającym cechę $\mathrm{B}(\mathrm{x})$.

Wynika stąd między innymi że

$$
\mathrm{c}=\mathrm{A}(\mathrm{B}(\mathrm{c}))
$$

oraz, że

$$
\mathrm{d}=\mathrm{B}(\mathrm{A}(\mathrm{d}))
$$

Przedmiot c jest więc takim przedmiotem, który z konieczności ma cechy $\mathrm{B}(\mathrm{x})$ i $\mathrm{A}(\mathrm{x})$, przedmiot zaś d jest takim przedmiotem, który z konieczności posiada cechy $\mathrm{A}(\mathrm{x})$ i $\mathrm{B}(\mathrm{x})$. Dlatego też dla dowolnie ustalonej kombinacji ${ }^{8}$ cech $\mathrm{A}(\mathrm{x})$ i $\mathrm{B}(\mathrm{x})$ jest taki przedmiot konkretny, który jest przedmiotem idealnym ze względu na tę kombinację cech. Zatem dla dowolnie ustalonej kombinacji cech $\mathrm{A}(\mathrm{x})$ i $\mathrm{B}(\mathrm{x})$ jest taki przedmiot, który z konieczności tę kombinację cech ma.

Dowód: N iech $\mathrm{A}(\mathrm{x})$ i $\mathrm{B}(\mathrm{x})$ będą dowolnymi ustalonymi cechami. Weźmy teraz pod uwagę dwa dowolnie ustalone przedmioty a i b, a następnie złożenie, czy fuzję $(a * b) * a$. Rozważmy dalej przedmioty konkretne $\mathrm{A}\left((\mathrm{a} * \mathrm{~b}){ }^{*} \mathrm{a}\right)$ oraz $\mathrm{B}((\mathrm{a} * \mathrm{~b}) * \mathrm{a})$, a następnie cechy $\mathrm{A}((\mathrm{x} * \mathrm{y}) * \mathrm{x})$ oraz $\mathrm{B}((\mathrm{x} * \mathrm{y}) * \mathrm{x})$ i ostatecznie czyste jakości $\mathrm{x} /(\mathrm{y} / \mathrm{A}((\mathrm{x} * \mathrm{y}) * \mathrm{x}))$ oraz $\mathrm{x} /(\mathrm{y} / \mathrm{B}((\mathrm{x} * \mathrm{y}) * \mathrm{x}))$. Dla większej jasności wprowadźmy następujące skróty definicyjne:

$$
\mathrm{x} /(\mathrm{y} / \mathrm{A}((\mathrm{x} * \mathrm{y}) * \mathrm{x}))={ }^{\mathrm{df}} \mathrm{a}
$$

oraz

$$
\mathrm{x} /(\mathrm{y} / \mathrm{B}((\mathrm{x} * \mathrm{y}) * \mathrm{x}))={ }^{\mathrm{df}} \mathrm{b}
$$

Spójrzmy teraz na fuzje $\left(\mathrm{a}^{*} \mathrm{~b}\right){ }^{*}$ a oraz $(\mathrm{b} * \mathrm{a}) *$ b. Otóż na mocy (1) i (4) mamy:

$$
\begin{aligned}
& (\mathrm{a} * \mathrm{~b}) * \mathrm{a}= \\
& (\mathrm{x} /(\mathrm{y} / \mathrm{A}((\mathrm{x} * \mathrm{y}) * \mathrm{x})) * \mathrm{~b}) * \mathrm{a}= \\
& \mathrm{y} / \mathrm{A}((\mathrm{b} * \mathrm{y}) * \mathrm{~b}) * \mathrm{a}= \\
& \mathrm{A}((\mathrm{b} * \mathrm{a}) * \mathrm{~b}) \\
& \text { oraz }
\end{aligned}
$$

${ }^{8}$ Terminu ,kombinacja” używamy tu w znaczeniu potocznym. W terminologii kombinatorycznej należałoby raczej mówić o ,wariacji”. 


$$
\begin{aligned}
& (\mathrm{b} * \mathrm{a}) * \mathrm{~b}= \\
& (\mathrm{x} /(\mathrm{y} / \mathrm{B}((\mathrm{x} * \mathrm{y}) * \mathrm{x})) * \mathrm{a}) * \mathrm{~b}= \\
& \mathrm{y} / \mathrm{B}((\mathrm{a} * \mathrm{y}) * \mathrm{a}) * \mathrm{~b}= \\
& \mathrm{B}((\mathrm{a} * \mathrm{~b}) * \mathrm{a})
\end{aligned}
$$

Dla dowolnych $\mathrm{A}(\mathrm{x})$ i $\mathrm{B}(\mathrm{y})$ są więc takie $\mathrm{c}$ i $\mathrm{d}$, że $\mathrm{c}=\mathrm{A}(\mathrm{d})$ i $\mathrm{d}=\mathrm{B}(\mathrm{c})$.

Istotnie $\mathrm{c}=(\mathrm{a} * \mathrm{~b}) * \mathrm{a}$, natomiast $\mathrm{d}=(\mathrm{b} * \mathrm{a}) * \mathrm{~b}$ lub, pomijajacc skróty definicyjne,

$$
\mathrm{c}=(\mathrm{x} /(\mathrm{y} / \mathrm{A}((\mathrm{x} * \mathrm{y}) * \mathrm{x})) * \mathrm{x} /(\mathrm{y} / \mathrm{B}((\mathrm{x} * \mathrm{y}) * \mathrm{x})))^{*} \mathrm{x} /(\mathrm{y} / \mathrm{A}((\mathrm{x} * \mathrm{y}) * \mathrm{x}))
$$

oraz

$$
\mathrm{d}=(\mathrm{x} /(\mathrm{y} / \mathrm{B}((\mathrm{x} * \mathrm{y}) * \mathrm{x})) * \mathrm{x} /(\mathrm{y} / \mathrm{A}((\mathrm{x} * \mathrm{y}) * \mathrm{x})))^{*} \mathrm{x} /(\mathrm{y} / \mathrm{B}((\mathrm{x} * \mathrm{y}) * \mathrm{x})) .
$$

Na podstawie przyjętych wcześniej założeń można oczywiście sformułować i uzasadnić wiele innych, bardziej ogólnych wniosków, ale z braku miejsca nie będziemy tego tutaj robić.

Ogólnie można zatem powiedzieć, że przekonanie o absolutnej wykonalności procesu abstrahowania i hipostazowania prowadzi nieuchronnie do tego, że w uniwersum ontologicznym pojawiają się pewne mniej lub bardziej dziwne przedmioty, takie jak na przykład przedmioty idealne. Z drugiej jednak strony trzeba tu jednak powiedzieć, że podzielane przez niektórych filozofów przekonanie o istnieniu takich przedmiotów nie jest jedynie wyrazem ich bujnej wyobraźni, lecz tylko konsekwencją pewnych, do pewnego stopnia intuicyjnych, założeń.

\section{Bibliografia}

Arystoteles, Kategorie i Hermeneutyka z dodaniem Isagogi Porfiriusza, tłum. K. Leśniak, Warszawa 1975.

Descartes R., Rozprawa o metodzie, tłum. W. Wojciechowska, Warszawa 1981.

Husserl E., Badania logiczne, t. 2. Badania dotyczace fenomenologii $i$ teorii poznania, cz. 1, tłum. J. Sidorek, Warszawa 2000.

Spinoza B. de, Etyka, tłum. I. Myślicki, Warszawa 1991.

Swift J., Podróże Gullivera, tłum. M. Słomczyński, Wrocław 1988. 